\title{
NGHIÊN CÚU ĐẶC ĐIỂM LÂM SÀNG VÀ TÌNH TRẠNG KHÁNG INSULIN Ở BỆNH NHÂN XƠ GAN
}

\author{
Trần Hũu Dàng ${ }^{1}$, Nguyê̂n Thái Bình ${ }^{1}$, Trần Thù̀a Nguyên ${ }^{2}$
}

1. Truờng Đại học Y Dược Huế; 2. Bệnh viện Trung ương Huế

DOI: $10.47122 / v j d e .2020 .44 .12$

\section{TÓM TẮT}

Muc tiêu: Nghiên cứu đặc điểm lâm sàng, cận lâm sàng và tình trạng kháng insulin ở bệnh nhân xơ gan. Đối tượng và phương pháp nghiên cúu: Chúng tôi tiến hành nghiên cứu mô tả, cắt ngang ở 50 bệnh nhân xơ gan (nhóm bệnh) và 50 đối tượng khoẻ mạnh (nhóm chứng). Tất cả đối tượng nghiên cứu được ghi nhận triệu chứng lâm sàng, cận lâm sàng và tiến hành định lượng nồng độ glucose máu đói và insulin máu đói. Mức độ đề kháng insulin được đánh giá dựa vào chỉ số HOMA do Matthew đề xuất. Điểm cắt giới hạn của chỉ số HOMA - IR lớn hơn tứ phân vị cao nhất của nhóm chứng tính theo insulin là 1,21. Xử lý số liệu bằng chương trình chương trình SPSS 22.0. Kết quả: Triệu chứng lâm sàng ở bệnh nhân thường gặp là nghiện rượu, mệt mỏi, giảm khả năng lao động, vàng da, vàng mắt, phù hai chân, cồ trướng và tuần hoàn bàng hệ. Các triệu chứng khác gặp với tỷ lệ ít hơn. Giá trị trung bình của các chỉ số prothrombin, albumin, hồng cầu, huyết sắc tố, tiểu cầu, glucose máu lúc đói giảm. Giá trị trung bình của các chỉ số bilirubin, men gan SGOT,SGPT, insulin máu lúc đói tăng. Tỷ lệ kháng insulin theo HOMA IR của đối tượng nghiên cứu là $86,0 \%$ (p < $0,01)$. Kết luận: Kháng insulin là yếu tố nguy cơ ở bệnh nhân xơ gan

Tù khóa: Kháng insulin, xơ gan.

\section{ABSTRACT \\ Study in clinical characteristics and insulin resistance status in patients with cirrhosis \\ Tran Huu Dang ${ }^{1}$, Nguyen Thai Binh ${ }^{1}$, Tran Thua Nguyen ${ }^{2}$ \\ 1. Hue University of Medicine and Pharmacy 2. Hue Central Hospital}

Objectives: To study on clinical features, and insulin resistance in patients with cirrhosis. Subjects and research methods: We conducted a study in 50 patients with cirrhosis (disease group) and 50 healthy subjects (control group). All study subjects were recorded clinical, and conducted quantitative fasting blood glucose and serum insulin. Insulin resistance is assessed by the HOMA index based on Matthew suggested. Restriction point of the index HOMA - IR greater than the highest quartile of insulin control groups was 1.21 calculated. Processing data using SPSS 22.0 program. Results: Clinical symptoms are common in patients with alcoholism, fatigue, reduced working capacity, jaundice, yellow eyes, edema, ascites and collateral circulation. Other symptoms met with a smaller proportion. The average level of the prothrombin, albumin, hemoglobin, hemoglobin, platelets, fasting blood glucose decreased. The average level of bilirubin, liver enzymes SGOT, SGPT, fasting blood insulin increased. HOMA- IR insulin resistance rate was $86.0 \%$ ( $p<0.01)$. Conclusions: Insulin resistance is a risk factor in patients with cirrhosis

Key words: Insulin resistance, cirrhosis.

Chịu trách nhiệm chính: Trần Hữu Dàng

Ngày nhận bài: 05/12/2020

Ngày phản biện khoa học: 08/12/2020

Ngày duyệt bài: 29/01/2021

Email: bsthdang@gmail.com

Điện thoại: 0913465427

\section{1. ĐẠT VẤN ĐỀ}

Gan là tạng lớn nhất trong cơ thể đóng vai trò quan trọng trong tiêu hóa, hấp thu, chiếm vị trí chủ chốt trong chuyển hóa những chất cần thiết như protid, cacbonhydrat và chuyển hóa lipid, tất cả đều được kiểm soát chặt chẽ bởi một loạt các hormon tiết ra từ các cơ quan khác nhau. Trong những hormon này sự có mặt của 
insulin đã được chứng minh có liên quan đến các chức năng chuyển hóa của gan và của toàn cơ thể [1].

Kháng insulin là sự suy giảm hiệu quả tác dụng sinh học của insulin trên tế bào đích, biểu hiện thông thường bằng gia tăng nồng độ insulin trong máu, kháng insulin được biết đến đầu tiên là tình trạng gia tăng nhu cầu insulin trong bệnh lý đái tháo đường týp 2 [3].

Mối liên quan giữa kháng insulin và xơ gan hiện nay đang là một chủ đề được đặc biệt quan tâm. Trên thế giới đã có nhiều nghiên cứu về vấn đề này, ở Việt Nam kháng insulin mới chỉ được nghiên cứu ở bệnh nhân đái tháo đường týp 2 , bệnh mạch vành, xơ gan, tai biến mạch não...Nhưng kháng insulin ở bệnh nhân xơ gan chưa được nghiên cứu nhiều. Từ thực tế đó để hiểu hơn về tình trạng kháng insulin ở bệnh nhân xơ gan, chúng tôi tiến hành nghiên cứu: "Nghiên cứu đặc điểm lâm sàng, cận lâm sàng và tình trạng kháng insulin ỏ bệnh nhân xo' gan".

\section{2. ĐỐI TƯợNG VÀ PHƯƠNG PHÁP NGHIÊN CÚU}

\subsection{Dối tượng nghiên cứu}

2.1.1. Nhóm bệnh

Bao gồm 50 bệnh nhân xơ gan điều trị tại khoa Nội tiêu hóa và khoa Lão khoa Bệnh viện Trung ương Huế, khoa Nội tổng hợp Bệnh viện Trường Đại Học Y Dược Huế.

2.1.2. Nhóm chúng (Dùng để tìm chỉ số HOMA - IR)

Bao gồm 50 người chứng, không bị xơ gan, viêm gan, gan nhiễm mõ̃, chưa được phát hiện chẩn đoán đái tháo đường, không nghiện rượu, tăng glyceride, béo phì, không sử dụng các thuốc ảnh hưởng đến glucose máu và insulin máu, tình nguyện tham gia nghiên cứu.

\subsection{Phương pháp nghiên cứu}

- Sử dụng phương pháp mô tả, thiết kế nghiên cứu cắt ngang.

- Mỗi bệnh nhân có một phiếu nghiên cứu chi tiết về tiền sử, bệnh sử, lâm sàng, cận lâm sàng với định lượng glucose, insulin máu.

\section{Đăc điểm chung}

- Tuổi

- Giới

- Thời gian phát hiện bệnh: < 1 năm, 1 - 3 năm, > 3 năm.

Nghiên cứu đặc điểm lâm sàng

- Triệu chứng lâm sàng: Vàng da, vàng mắt, sao mạch, lòng bàn tay son, phù hai chân, cổ trướng, xuất huyết dưới da, gan to, lách to, tuần hoàn bàng hệ, rối loạn tiêu hóa.

Nghiên cứu đặc điểm cận lâm sàng

- Huyết học: Hồng cầu, huyết sắc tố, hematocrit, thể tích trung bình hồng cầu (MCV), bạch cầu, tiểu cầu.

- Xét nghiệm viêm gan virus B, C.

- Xét nghiệm đông máu cơ bản: Tỷ lệ prothrombin.

- Sinh hóa: Định lượng insulin lúc đói, glucose lúc đói, SGOT/SGPT, bilirubin toàn phần, protein, albumin.

- Siêu âm gan: Kích thước gan, kích thước lách, đường kính tĩnh mạch cửa, dịch ổ bụng.

\subsection{Phương pháp xử lý số liệu}

- Xử lý số liệu theo phương pháp thống kê $\mathrm{y}$ học bằng phần mềm SPSS 22.0.

\section{KÊTT QUẢ NGHIÊN CÚ̉U}

\section{1. Đặc điểm về tuổi}

Bảng 3.1. Đặc điểm về tuổi của đối tượng nghiên cứu

\begin{tabular}{|c|c|c|c|}
\hline \multicolumn{2}{|c|}{ Đặc điểm } & Số bệnh nhân & Tỷ lệ \% \\
\hline \multirow{4}{*}{ Tuổi } & $<40$ tuồi & 4 & 8,0 \\
\cline { 2 - 4 } & $40-60$ tuồi & 38 & 76,0 \\
\cline { 2 - 4 } & $>60$ tuồi & 8 & 16,0 \\
\cline { 2 - 4 } & Tồng & 50 & 100,0 \\
\hline
\end{tabular}

Nhận xét:

- Nhóm tuổi 40 - 60 chiếm tỷ lệ cao nhất $(76,0 \%)$, thấp nhất ở nhóm tuổi $<40(8,0 \%)$. 


\section{2. Đặc điểm lâm sàng}

Bảng 3.2. Đặc điểm lâm sàng của đối tượng nghiên cứu

\begin{tabular}{|l|c|c|}
\hline \multicolumn{1}{|c|}{ Đặc điểm lâm sàng } & Số bệnh nhân & Tỷ lệ \% \\
\hline Nghiện rượu & 36 & 72,0 \\
\hline Mệt mỏi, giảm khả năng lao động & 49 & 98,0 \\
\hline Rối loạn tiêu hóa & 13 & 26,0 \\
\hline Vàng da, vàng mắt & 49 & 98,0 \\
\hline Sao mạch, bàn tay son & 21 & 42,0 \\
\hline Phù hai chân & 39 & 78,0 \\
\hline Cổ trướng & 32 & 64,0 \\
\hline Tuần hoàn bàng hệ & 30 & 60,0 \\
\hline Gan to & 19 & 38,0 \\
\hline Lách to & 24 & 48,0 \\
\hline Tổng & 50 & 100,0 \\
\hline
\end{tabular}

\section{Nhận xét:}

Triệu chứng lâm sàng ở bệnh nhân thường gặp là nghiện rượu, mệt mỏi, giảm khả năng lao động, vàng da, vàng mắt, phù hai chân, cổ trướng và tuần hoàn bàng hệ. Các triệu chứng khác gặp với tỷ lệ ít hơn.

\section{3. Đặc điểm một số xét nghiệm huyết học, sinh hoá}

Bảng 3.3. Đặc điểm một số xét nghiệm huyết học, sinh hoá của đối tượng nghiên cứu

\begin{tabular}{|l|c|c|}
\hline \multicolumn{1}{|c|}{ Các chỉ số xét nghiệm } & n & $\bar{X} \pm$ SD \\
\hline Tỷ lệ prothrombin $(\%)$ & 50 & $53,38 \pm 18,16$ \\
\hline Albumin $(\mathrm{g} / \mathrm{l})$ & 50 & $27,38 \pm 5,35$ \\
\hline Bilirubin TP $(\mu \mathrm{mol} / \mathrm{l})$ & 50 & $99,10 \pm 258,42$ \\
\hline Bilirubin trực tiếp $(\mu \mathrm{mol} / \mathrm{l})$ & 50 & $48,05 \pm 131,65$ \\
\hline Bilirubin gián tiếp $(\mu \mathrm{mol} / \mathrm{l})$ & 50 & $36,95 \pm 36,50$ \\
\hline Men gan SGOT $(\mathrm{U} / \mathrm{l})$ & 50 & $123,94 \pm 107,33$ \\
\hline Men gan SGPT $(\mathrm{U} / \mathrm{l})$ & 50 & $63.27 \pm 72,69$ \\
\hline Số lượng hồng cầu $(\mathrm{T} / \mathrm{l})$ & 50 & $3,29 \pm 0,68$ \\
\hline Số lượng bạch cầu $(\mathrm{G} / \mathrm{l})$ & 50 & $4,94 \pm 2,45$ \\
\hline Huyết sắc tố $(\mathrm{G} / \mathrm{l})$ & 50 & $11,59 \pm 10,93$ \\
\hline Số lượng tiểu cầu $(\mathrm{G} / \mathrm{l})$ & 50 & $87,29 \pm 76,05$ \\
\hline Glucose máu lúc đói $(\mathrm{mmol} / \mathrm{l})$ & 50 & $5,52 \pm 2,14$ \\
\hline Insulin máu lúc đói $(\mu \mathrm{U} / \mathrm{ml})$ & 50 & $8,67 \pm 6,8$ \\
\hline
\end{tabular}

Nhận xét:

Giá trị trung bình của các chỉ số prothrombin, albumin, hồng cầu, huyết sắc tố, tiểu cầu, glucose máu lúc đói giảm. Giá trị trung bình của các chỉ số bilirubin, men gan SGOT,SGPT, insulin máu lúc đói tăng. 


\subsection{Nguyên nhân xơ gan}

Bảng 3.4. Nguyên nhân xơ gan của đối tượng nghiên cứu

\begin{tabular}{|l|c|c|}
\hline \multicolumn{1}{|c|}{ Nguyên nhân xo' gan } & Số bệnh nhân & Tỷ lệ \% \\
\hline Do virus & 8 & 16,0 \\
\hline Do rượu & 23 & 46,0 \\
\hline Do virus và do rượu & 13 & 26,0 \\
\hline Nguyên nhân khác & 6 & 12,0 \\
\hline \multicolumn{1}{|c|}{ Tổng } & 50 & 100,0 \\
\hline
\end{tabular}

Nhận xét: Xơ gan do rượu đơn thuần chiếm tỷ lệ cao nhất 46,0\%. Xơ gan do nguyên nhân khác chiếm tỷ lệ thấp nhất $12 \%$, ở hai nhóm nguyên nhân xơ gan còn lại chiếm tỷ lệ lần lượt $26 \%$ và $16 \%$.

\subsection{Tỷ lệ kháng insulin theo HOMA - IR}

Bảng 3.5. Tỷ lệ kháng insulin theo HOMA - IR của đối tượng nghiên cứu

\begin{tabular}{|c|c|c|c|}
\hline HOMA - IR & Số bệnh nhân & Tỷ lệ \% & p \\
\hline$>1,21$ (kháng insulin) & 43 & 86,0 & \multirow{2}{*}{$<0,01$} \\
\hline$\leq 1,21$ (Không kháng insulin) & 7 & 14,0 & \\
\hline Tổng & 50 & 100,0 & \\
\hline
\end{tabular}

Nhận xét: Bệnh nhân xơ gan có tỷ lệ kháng insulin $86,0 \%$ cao hơn so với bệnh nhân xơ gan không kháng insulin 14,0\%, có ý nghĩa thống kê với $\mathrm{p}<0,01$.

\section{BÀNLUẬN}

Bệnh nhân xơ gan có triệu chứng mệt mỏi và giảm khả năng lao động gặp với tỷ lệ cao $98,0 \%$. Tiếp đến triệu chứng vàng da, vàng mắt $98,0 \%$; phù chân 78,0\%, nghiện rượu 72,0\%. Các triệu chứng khác gặp với tỷ lệ thấp hơn.

Biểu hiện của hội chứng tăng áp lực tĩnh mạch cửa trong nghiên cứu của chúng tôi nhận thấy cổ trướng chiếm tỷ lệ $64,0 \%$, tuần hoàn bàng hệ $60,0 \%$, lách to $48,0 \%$, gan to $38,0 \%$. Cổ trướng là biểu hiện thường gặp ở bênh nhân xơ gan, đặc biệt là xơ gan giai đoạn mất bù. Cổ trướng được định nghĩa là sự tích tụ của chất lỏng bệnh lý trong các khoang phúc mạc. Theo nghiên cứu của tác giả Bird Tom $G$ và nghiên cứu của Tsochazis $\mathrm{E}$. A có khoảng $85 \%$ bệnh nhân xơ gan có cổ trướng [5].

Về cận lâm sàng ở bảng 3.3 chúng tôi thấy có sự suy giảm rõ rệt về tỷ lệ prothrombin, albumin, hồng cầu, huyết sắc tố và tiểu cầu. Trong khi đó các chỉ số bilirubin máu, men gan và insulin máu tăng.

Kết quả nghiên cứu của chúng tôi ở bảng 3.5 cho thấy: Trong 50 đối tượng nghiên cứu có tổng số 43 bệnh nhân xơ gan có kháng insulin chiếm tỷ lệ $86,0 \%$ và 07 bệnh nhân xơ gan không kháng insulin chiếm tỷ lệ $14,0 \%$ $(\mathrm{p}<0,01)$.

Kết quả nghiên cứu của chúng tôi tương tự với nghiên cứu của các tác giả: Nghiên cứu của Đinh Thị Ánh Nguyệt cũng có tỷ lệ kháng insulin theo HOMA - IR là $53,2 \%$ và không kháng insulin chiếm tỷ lệ 46,8\% [2]. Nghiên cứu của Takumi $\mathrm{K}$. có tỷ lệ kháng insulin $57,0 \%$ [4].

\section{KẾT LUẬN}

Qua nghiên cứu 50 bệnh nhân xơ gan dựa vào đặc điểm lâm sàng, cận lâm sàng, Child Pugh và kháng insulin theo chỉ số HOMA chúng tôi rút ra một số kết luận sau:

- Triệu chứng mệt mỏi giảm khả năng lao động $98,0 \%$, vàng da vàng mắt $98,0 \%$, phù hai chân $78,0 \%$, nghiện rượu $72,0 \%$, cồ trướng $64,0 \%$ là triệu chứng hay gặp nhất. Các triệu chứng khác gặp với tỷ lệ ít hơn.

- Giá trị trung bình tăng ở các chỉ số bilirubin toàn phần $99,10 \pm 258,42(\mu \mathrm{mol} / \mathrm{ml})$, men gan SGOT 123,94 $\pm 107,33(\mathrm{U} / \mathrm{L}), \mathrm{SGPT}$ $63,27 \pm 72,69(\mathrm{U} / \mathrm{L})$, insulin máu lúc đói 8,67 $(\mu \mathrm{U} / \mathrm{ml})$. 
- Giá trị trung bình giảm ở các chỉ số tỷ prothrombin 53,38 $\pm 18,16(\%)$, albumin 27,38 $\pm 5,35(\mathrm{~g} / \mathrm{l})$, hồng cầu $3,29 \pm 0,68(\mathrm{~T} / \mathrm{l})$, huyết sắc tố $11,59 \pm 2,14(\mathrm{G} / 1)$, tiểu cầu $87,29 \pm$ $76,05(\mathrm{G} / 1)$, glucose máu lúc đói $5,52 \pm 2,14$ $(\mu \mathrm{mol} / \mathrm{l})$.

- Tỷ lệ kháng insulin theo HOMA - IR của đối tượng nghiên cứu là $86,0 \%(\mathrm{p}<0,01)$.

\section{TÀI LIÊU THAM KHẢO}

1. Hà Văn Mạo (2014), "Xơ gan", Bệnh hoc gan mật tuy, Hội gan mật Việt Nam, Nhà xuất bản Y Học, Hà Nội, tr. 476-494.

2. Đinh Thị Ánh Nguyệt (2013), Nghiên cúu tình trạng kháng insulin ở bệnh nhân xo' gan điều trị tại Bệnh viện Đa khoa Trung uoong Thái Nguyên, Luận văn tốt nghiệp Bác sĩ Nội trú, Trường Đại học Y Dược Đại Học Thái Nguyên, tr. 1-76.

3. Thái Hồng Quang (2012), "Bệnh béo phì", Thực hành lâm sàng bệnh đái tháo đường, Nhà xuất bản Y Học, Hà Nội, tr. 379-413.

4. Takumi K., Eitaro T., et al (2011), "Insulin resistance and chronic liver disease", World J Hepatol 3(5), pp. 99107.

5. Tsochatzis Emmanuel A., Bosch Jaime, Burroughs Andrew K. (2014), "Liver cirrhosis", The Lancet, 383(9930), pp. 1749-1761. 